\title{
Warhol's Apiary: A Review of Farming the City
}

Book review by Christian Man, Memphis Center for Food and Faith

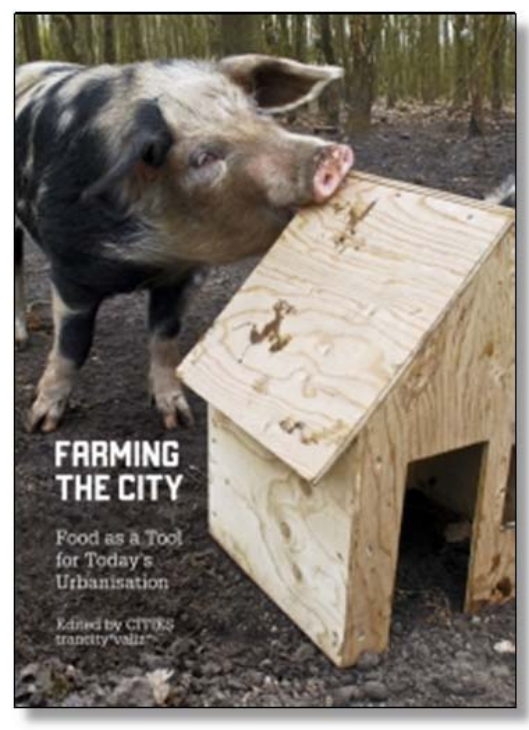

\section{Farming the City: Food as a Tool for Today's Urbanisation}

Miazzo, F., \& Minkjan, M. (Eds.). (2013). Farming the city: Food as a tool for today's urbanisation. Amsterdam: Trancity*Valiz.

Published online September 13, 2013

Citation: Man, C. (2012). Warbol's apiary: A review of Farming

the City [Book review]. Journal of Agriculture, Food Systems,

and Community Development, 3(4), 33-34.

http://dx.doi.org/10.5304/jafscd.2013.034.023

Copyright (C) 2013 by New Leaf Associates, Inc.

$\mathrm{T}$ he first thing we notice about Farming the City is its hilarious cover: a wire-haired, black-andtan hog chewing blithely on the side of a wooden roof that presumably shelters its young. Glancing below at the title, we wonder: Is that an urban pig? Is that a public park? Was that lumber pressuretreated?

The early onset of curiosity here is perhaps apt, anticipating as it does Farming the City's own sustained wonderment with food. Yes, here is a volume that does not (that cannot!) understate its infatuation with the beauty of planted and fourlegged (and two-legged) things. Printed with vegetable-based inks on surplus paper, fully onethird of the book's pages are filled with sumptuous photographs: oyster mushrooms growing from PVC pipes in cool, protected alleys; rooftop beehives plastered with Warholesque renderings; great trees in Central Tokyo sagging with bright orange persimmons. Thumbing through the pages, you think: It is a wondrous place, Earth!

Farming the City is "a compilation of explana- tions, insights, case studies, exemplars and critical analysis from practitioners and experts in the food field" (p. 7). It also "outlines ways of using food as a tool to approach the many challenges inherent in contemporary urban life from a human, locallyoriented perspective" (p. 3). Well, in addition, "it aims to trace a path towards a socially, culturally and economically resilient society; a place where inclusive, locally-oriented modes of production are not only possible, but preferable" (p. 3). Which is to say that "the key question is: how can innovative food initiatives contribute to the re-interpretation and reshaping of urban dynamics in a physical, economic, social and technological sense" (p. 227).

If you haven't gone to lie down in a quiet place by now and are still reading, that probably means you are not new to the popular literature on urbanism (-ization, -ists, et al.). Noble and thoughtful, this kind of manifesto rhetoric is commonplace today. To be sure, it invokes real problems, but as it does it imbues a thing (food in this case) with messianic promise. No, food is not just a "tool" 
but an ideology, a plausibility structure through which we can make sense of, and reassemble, the world. Largely absent is a fascination with actuallyexisting solutions. In other words - and as we will see - ideation is the book's main intellectual contribution.

Thanks to a clean, spare aesthetic, Farming the City has four main sections that are easy to navigate. The first is about food policy and what the editors call "the food field." With contributions from designers, planners, and academics, these essays theorize in turn about food security, food chains, resilience, systems thinking, and "continuous productive urban landscapes." Much of this will be review for readers, although Independent researcher and designer Paul de Graaf's chapter in particular reiterates some critical points on urban agriculture. On the role of so-called "experts": they "do well to remain realistic about their role" (p. 38). On the tendency for top-down approaches: "[Urban agriculture] is driven by bottom-up initiatives and the key designers are urban farmers themselves" (p. 38). On systems thinking: "Some aspect of 'big picture' planning is necessary to make the whole more than the sum of its parts" (p. 38).

Other essays in section one struggle to convince the reader that their policy recommendations are not, in fact, just big ideas. For instance, Pim Vermeulen, senior planner for the city of Amsterdam, contributes a chapter on regional food chains. In his conclusion, he recommends policies such as "improving the image of vocational training institutes in the food sector" and "encourag[ing] retail and catering companies to promote more healthy and sustainable eating habits." Weirdly, such recommendations are disembodied from the economic, political, and project-specific contexts in which public policy either lives or dies.

Section two focuses on "food economies and their relationship with a new social topography." Here Derek A. Denckla, chair of Slow Money NYC, makes some refreshingly grounded points. "Advocates of urban agriculture should remember that farming is a business," he writes. "On-going efforts by government, business and activists should be directed to ensure that urban farms may be financially viable in order to provide long-term social, cultural and environmental benefits to cities" (p. 57). Even stronger is the chapter by Jennifer Sumner, J. J. McMurty, and Michael Classens on urban food security, which considers Toronto-based FoodShare's Good Food Market (GFM) program. Their chapter attends carefully to the gritty nuances of program implementation, while also considering the effects of headier issues like neoliberalism and austerity politics. What is more, the authors are realistic. "The GFM programme in Toronto demonstrates the complexity of re-shaping the conventional food system," they write, "while shedding light on the limits and possibilities of using food as a tool for urban development" (p. 77).

As with section one, other essays in section two struggle to compel. Dr. Oran B. Hesterman, president and CEO of Fair Food Network, goes into detail about his organization's program, Double Up Food Bucks (DUFB). DUFB doubles the value of American Supplemental Nutrition Assistance Program vouchers when redeemed at participating farmers' markets. This is an ingenious idea, and Dr. Hesterman is to be commended for his pioneering leadership. However, the absence of any critical consideration of the program - e.g., how it will be funded in the long run - is, well, odd. Elsewhere, Jan-Willem van der Schans's chapter on foodscapes seems intelligent, but indecipherably so. I am still trying to figure out what he means by a "multi-functional territorial integrative perspective."

The third and especially the fourth sections are much more straightforward. They look at different food projects unfolding in urban communities throughout the world. Despite the re-occurrence of manifesto rhetoric here and there, the book now hits its stride. Finally, the reader can just revel in the pleasures of the Japanese kaki dorobou (hint: persimmons); the exquisite design of French periurban gardens; rooftop hydroponic operations galore; and not least the Plant Tram, a long wooden flower bed that winds about like a colorful rollercoaster, swerving whimsically to and fro in the shadow of a shuttered Helsinki power plant.

In sum, here is a book that, in its finest moments, reminds us to mix pleasure into the work for good food. This is wise, unconventional advice. 